\title{
Expression of Syndecan Gene during Tooth Organogenesis
}

\author{
歯の形成時に発現するシンデカン遺伝子
}

Jalkanen, V.S., Vaahtokari, A., Sahlberg, C., Mali, M., Bernfield, M., and Thesleff, I. Development. Biol. (1991) 147, $322-333$

Key Words: gene expression, organogenesis, proliferation, syndecan, tooth

The notion that proteoglycans have functional roles in differentiation, cell-cell interaction, and cell locomotion has not been well substantiated by experimental evidence. In vitro interaction studies between proteoglycans and other macromolecules are suggestive of such biologicasl roles. Since last year many researchers have addressed this problem by using the molecular biology tools. The present investigators have chosen an appropriate model of tooth organogenesis in embryonic mouse to study the functional role of syndecan, a resident heparan sulfate proteoglycan of integral transmembrane of epithelial and mesenchymal cells. There are four distinct phases in tooth morphogenesis in which there is invagination of the epithelium into the underlying jaw mesenchyme which forms bud, the cap and bell stages involving cell proliferation, the late bell stages ending in terminal differentiation. The mesenchymal cells give rise to odontoblasts secreting the organic matrix of the dentin. The epithelial cells differentiate into ameloblasts which produce the enamel matrix. The investigators have analysed changes in syndecan gene expression during tooth development with RNA in situ hybridization, Northern and slot-blot analyses and compared the distribution patterns of syndecan mRNA with its core protein. Moreover, these investigators have examined the association of syndecan expression with cell proliferation by immunohistochemical detection of Bromodeoxyuridine(BrdU) incorporation. Furthermore, they have examined the role of tissue interactions in the regulation of syndecan gene expression in co-culture system of separated and recombined dental epithelium and mesenchyme.

Results obtained can be summarized as follows: In situ hybridization analysis of the tooth buds showed accumulation of grains in condensed mesenchymal cells. This distribution of syndecan gene transcripts was similar to the syndecan core protein suggesting that the mesenchyal cells which transcribe the syndecan gene into mRNA further translates it into core protein. The incorporation of BrdU was also at the same site indicating rapid cell proliferation. At the cap stage, syndecan trascripts were present in the dental papila mesenchyal cells. The expression of syndecan mRNA and BrdU incorporation were also identical. In contrast, there was a decrease in the syndecan transcripts in the epithelial cells. At the bell stage, the inner enamel epithelium expressed the syndecan gene and its core protein weakly. However, there was an accumulation of syndecan transcripts in the dental lamina. At the late bell
プロテオグリカンが細胞分化、細胞間相互作用、細胞移動 などに機能的役割を果たしているという説には、実験的に十分 な裹付けがなかった。in vitroでのプロテオグリカンと他の高分 子との相互作用の研究から、プロテオグリカンもこのような役 割が示唆されていたに過ぎない。昨年以来、分子生物学的手法 を用いてこの問題を扱った多くの研究が出ている。今回紹介す る論文の著者達は、上皮および間充織細胞の内在的膜貫通型ブ ロテオグリカンであるへパラン硫酸、つまりシンデカンの機能 的役割を調べるため、マウス胚における歯の器官形成という格 好のモデルを選んでいる。歯の器官形成は4段階に分けられる。 先ず上皮がそれを裹打ちしている頧の間充織に陥入して菊芽を つくる(蕾状期)。歯芽は細胞增殖をして帽状期、次に鐘状期と なり、鐘状期後期は最終分化の状態である。間充織細胞から は、象牙質の有機マトリックスを分泌する象牙芽細胞が生じ る。上皮細胞はエナメル質を作るエナメル芽細胞に分化する。 この著者達は歯の発生の間のシンデカン遗伝子発現を、RNAに ついて、in situハイブリダイゼーション、ノーザンブロット、そ してスロットブロット分析で調ベ、シンデカンのコアタンパク のmRNAの分布パターンを較べた。さらに彼らはシンデカンの 発現と、ブロモデオキシウリジン(BrdU)の取り込みを免疫組織 化学的方法で検出して細胞增殖との関連を調べている。その上 彼らは、上皮と間充織を別々に、あるいは再構成した培養系を 用いて、組織間相互作用がシンデカン遺伝子発現を制御するか どうか調べている。

得られた結果をまとめると次のようになる。歯芽をin situ ハイブリダイゼーションで調べると、凝集した間充織細胞に粒 子が多く集まっていた。シンデカン遺伝子転写物の分布は、シ ンデカンコアタンパク質のそれと同じなので、シンデカン遺伝 子をmRNAに転写している間充織細胞はさらにそのmRNAを翻 訳してコアタンパク質にしていることになる。同じ場所での $\mathrm{BrdU}$ の取り込みは急速な細胞増殖を示している。帽状期ではシ ンデカン転写物は歯乳頭の間充織細胞に存在していた。シンデ カンmRNAの発現とBrdUの取り込みもまた同じであった。対照 的に上皮細胞でのシンデカン転写物は减少していた。鐘状期に なると、内側のエナメル上皮でのシンデカン遺伝子とシンデカ ンコアタンパク質の発現は弱くなっていた。しかし、歯堤では シンデカン転写物が蓄積していた。鐘状期後期では、最終分化 段階に至った結果、シンデカン転写物は完全に失われた。これ 
stages, as a result of terminal differentiation there was a complete loss of syndecan transcripts. These histochemical observations were confirmed by measuring the relative binding of the radiolabeled syndecan cDNA probe with the total RNA isolated from tissues and the amount of the ribosomal RNA in the sample. In addition Northern blot analysis was performed to confirm these results. Northern blot analysis indicated eight fold increase in the amount of $2.6 \mathrm{~kb}$ RNA encoding syndecan core protein in the mesenchymal cells. The role of epithelialmecenchymal interaction in the regulation of syndecan gene expression during tooth development was studied by co-culturing mesenchyal and epithelial cells isolated from 11 days embryos for 24 hours and measuring the relative amounts of syndecan transcripts. Results were supportive of other findings. In sum, these observations suggest that growth stimulating signals are involved in tissue interactions during early tooth organogenesis. The precise nature of these inductive signaling is not known at present. However, it is likely that growth factors in the TGF- $\beta$ and fibroblast growth factor families are involved. Interactions between syndecan and growth factors during tooth development are possible since members of TGF$\beta$ family are expressed during organogenesis. It is possible that syndecan regultes the levels of growth factors affecting cell proliferation.

Reported by Shridhar P. Damle

The Rockefeller University, New York 10021-6399, USA
らの組織化学的観察は、組織から抽出した全RNAと放射標識し たシンデカンcDNAとの相対的結合や、試料中のリボソーム RNA量を調べることで確認された。さらに、ノーザンブロット 解析法も䊅果を碓認するために行われている。ノーザンブロッ トによると間充織細胞ではシンデカンのコアタンパクをコード する2.6 kbRNAの量が8倍に增えていた。11日胚から単離した間 充織と上皮細胞を24時間共培養し、シンデカン転写物の相対量 を測定することで、歯の発生時に、上皮-間充織相互作用がシン デカン遗伝子発現に果たす役割を調べている。この䊅果は他の 知見をよく支持している。まとめると、これらの観察は、成長 刺激シグナルが初期の歯の器官形成時の組織間相互作用の中に 含まれていることを示唆している。この誘導的シグナル伝達の 正確な性質はまだ不明である。しかし、TGF- $\beta$ やFGFファミリ 一の成長因子が含まれているらしい。器官形成の間にTGF- $\beta$ ファミリーの幾つかが発現するので、歯の発生時にシンデカン と成長因子の間の相互作用は大いに起こり得る。シンデカンは 成長因子のレベルを制御することで細胞增殖に影響を及はして いるらしい。

ロックフェラー大学

Shridhar P. Damle

三菱化成生命科学研究所 · 複合糖質研究室 山形達也 訳 